\title{
COLLABORATIVE GOVERNANCE DALAM PROGRAM PERBAIKAN RUMAH TIDAK LAYAK HUNI DI KOTA SURAKARTA
}

\section{COLLABORATIVE GOVERNANCE IN THE REPAIR PROGRAM FOR UNNIVABLE HOUSES IN THE CITY OF SURAKARTA}

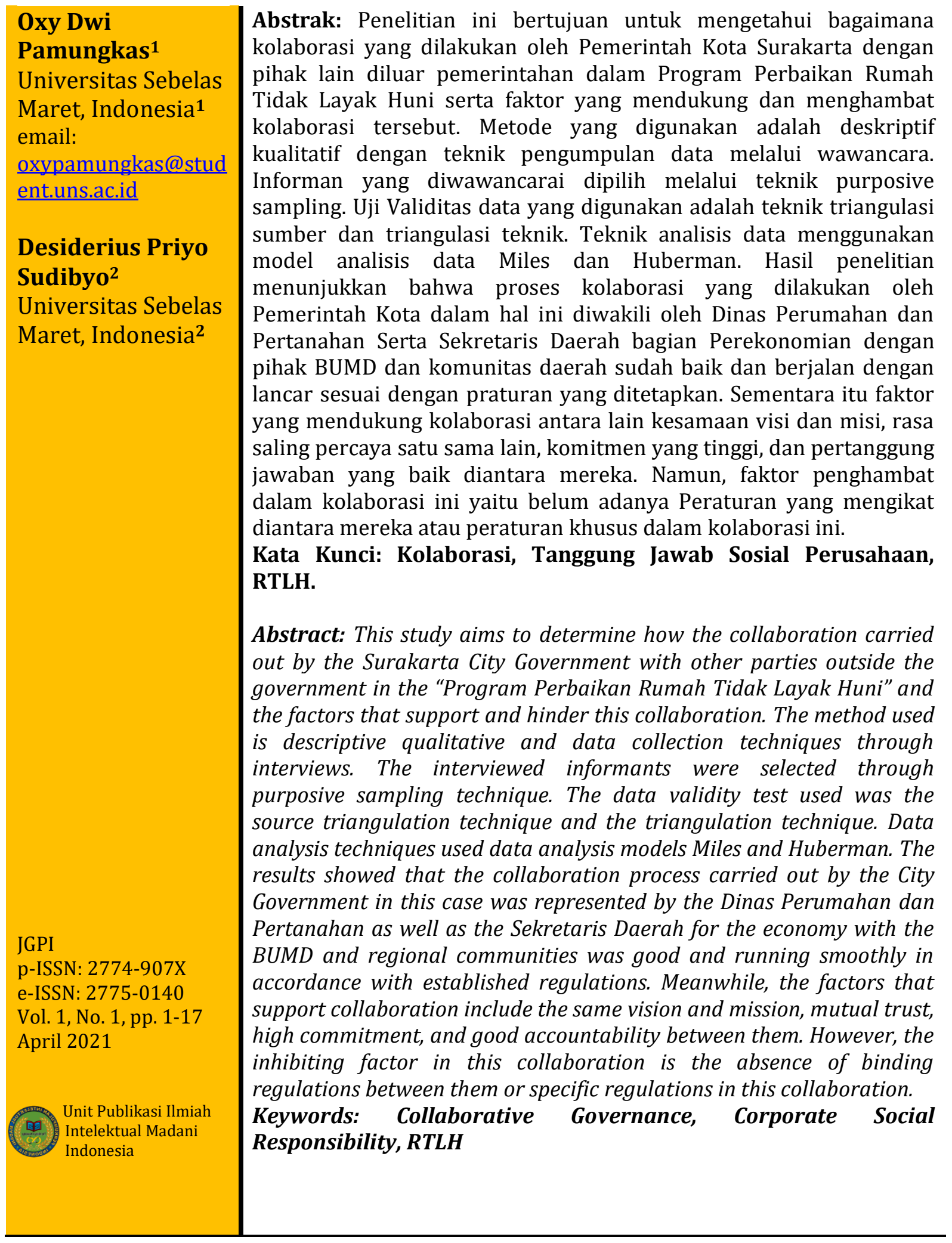




\section{PENDAHULUAN}

Pengentasan kemiskinan melalui kemitraan merupakan suatu usaha yang sedang digenjot pemerintah dalam beberapa tahun terakhir. Pemerintah mengajak perusahaan swasta, BUMN, BUMD maupun pihak lain untuk berkolaborasi membantu pemerintah dalam usahanya untuk mengentaskan kemiskinan melalui Corporate Social Responsibility (CSR) yang dimiliki setiap perusahaan.

Kolaborasi yang dapat dilakukan diatur dalam Peraturan Presiden Republik Indonesia Nomor 38 Tahun 2015 tentang Kerjasama Pemerintah dengan Badan Usaha dalam Penyediaan Infrasturktur. Dalam Peraturan Presiden tersebut disebutkan bahwa Badan Usaha milik swasta dapat bekerjasama dengan pemerintah guna mencapai percepatan pembangunan yang menitikberatkan pada pengentasan kemiskinan. Konsep Collaborative Governance sebagai sebuah alternatif dinilai mampu mewujudkan percepatan dan implementasi pemenuhan hak-hak untuk membantu mengentaskan kemiskinan. Collaborative Governance merupakan sebuah proses yang di dalamnya melibatkan berbagai stakeholder yang saling terkait untuk mengusung kepentingan masing-masing instansi dalam mencapai tujuan bersama (Hartman, et al, 2002).

Istilah kolaborasi, partnership/kemitraan dan kooperatif/kerjasama dalam beberapa tahun terakhir sering diucapkan oleh beberapa pihak ketika merujuk pada satu topik yang sama, yaitu masalah kerjasama antara pemerintah dan pihak lain. Kemitraan merupakan kerja sama formal antara individu-individu, kelompok-kelompok atau organisasi-organisasi untuk mencapai suatu tugas atau tujuan tertentu (Rahajeng \& Manaf, 2015). Namun biasanya, istilah kemitraan atau partnership ini digunakan untuk hubungan dalam konteks bisnis. Dalam perjalanannya, kemitraan ini bisa bersifat longgar seperti hanya berkoordinasi, atau bersifat lebih mengikat seperti kerjasama/ kooperatif dan kolaborasi.

Sementara itu, istilah kerjasama juga mengacu pada hubungan antara dua atau lebih pihak untuk mencapai tujuan bersama, namun dengan cara atau metode yang sama pula. Motivasi utamanya biasanya adalah memperoleh kemanfaatan bersama (hasil yang saling menguntungkan) melalui pembagian tugas. Kerjasama umumnya dilakukan untuk memecahkan persoalan dalam lingkungan dan sistem yang kompleks. Menurut Abdulsyani, kerjasama adalah suatu bentuk proses sosial, dimana didalamnya terdapat aktivitas tertentu yang ditunjukkan untuk mencapai tujuan bersama dengan saling membantu dan saling memahami aktivitas masing-masing (Abdulsyani, 1994). 
Selanjutnya, istilah kolaborasi biasanya digunakan untuk menjelaskan praktik yang dilakukan oleh dua pihak atau lebih untuk mencapai tujuan bersama dan melibatkan proses kerja masing-masing maupun kerja bersama dalam mencapai tujuan bersama tersebut. Motivasi utama dalam kolaborasi biasanya adalah untuk memperoleh hasilhasil kolektif yang tidak mungkin dicapai jika masing-masing pihak bekerja sendirisendiri. Berbeda dari istilah yang lain, kolaborasi biasanya dilakukan agar kemungkinan memunculkan/berkembangnya rasa saling pengertian dan realisasi dikarenakan adanya visi yang sama dalam lingkungan dan sistem yang kompleks. Kolaborasi merupakan upaya mengumpulkan berbagai pihak dengan kepentingan berbeda untuk menghasilkan visi bersama, membangun kesepakatan mengenai suatu masalah, menciptakan solusi untuk masalah tersebut, dan mengedepankan nilai-nilai bersama untuk menghasilkan keputusan yang menguntungkan semua pihak (Sridharan \& Simatupang, 2009).

Sementara itu, Di Indonesia sendiri Corporate Social Responsibility (CSR) bukanlah hal baru dalam peraturan perundang-undangan yang berlaku saat ini. Sejumlah peraturan termasuk yang bersifat sektoral telah mengatur mengenai CSR di berbagai bidang. Beberapa diantaranya yaitu: 1) Undang-Undang Nomor 40 Tahun 2007 tentang Perseroan Terbatas, 2) Peraturan Pemerintah Nomor 47 Tahun 2012 tentang Tanggung Jawab Sosial dan Lingkungan Perseroan Terbatas, 3) Undang-Undang Nomor 13 Tahun 2011 tentang Penanganan Fakir Miskin 4. Peraturan Menteri BUMN PER02/MBU/7/2017.

Di Kota Surakarta sendiri, juga mempunyai regulasi yang sama mengenai CSR yaitu Perda Kota Surakarta Nomor 2 Tahun 2015 tentang Tanggung Jawab Perusahaan serta Perwali No 3-A Tahun 2016 tentang Petunjuk Pelaksanaan Perda Kota Surakarta Nomor 2 Tahun 2015 yang dalam perkembangannya dirubah dalam Perwali Nomor 27A Tahun 2018 Tentang Petunjuk Pelaksanaan Peraturan Daerah Kota Surakarta Nomor 2 Tahun 2015 Tentang Tanggung Jawab Sosial Perusahaan. Dalam Perda Kota Surakarta ini, menitikberatkan pada pemberian kepastian dan perlindungan hukum atas pelaksanaan program TJSP, memberikan arah kepada perusahaan dan pemangku kepentingan dalam menyiapkan diri memenuhi standar internasional; dan mensinergikan pelaksanaan TJSP dengan program pembangunan berkelanjutan di daerah dengan tetap memperhatikan kelestarian fungsi lingkungan, pertumbuhan ekonomi, dan pengurangan tingkat kemiskinan. 
Uniknya, dalam Pasal 13 Perda Kota Surakarta Nomor 2 Tahun 2015 dijelaskan bahwa untuk memadukan, mensinkronisasikan dan mengharmonisasikan program TJSP, beberapa perusahaan dapat membentuk Forum Komunikasi TJSP dengan Walikota memfasilitasi pembentukan Forum Komunikasi TJSP dan Forum Komunikasi TJSP terdiri dari perusahaan dan unsur pemerintah daerah. Dengan adanya forum tersebut maka diharapkan program skala prioritas dari pemerintah daerah dapat digunakan sebagai bahan pertimbangan perusahaan dalam merencanakan pelaksanaan TJSP agar di lapangan terjadi keharmonisan antara upaya pemerintah daerah dengan kegiatan swasta. Dengan adanya Forum Komunikasi TJSP tersebut maka mengindikasikan terbentuknya suatu konsep yang dinamakan governance. Dalam konsep governance, pemerintah hanyalah salah satu aktor dan bertindak bukan sebagai aktor kunci didalam implementasi suatu kebijakan. Implikasinya, peran pemerintah yang biasanya bertindak sebagai pembangun maupun penyedia layanan atau infrastruktur akan bergeser menjadi pendorong terciptanya lingkungan atau konsep yang mampu memfasilitasi pihak lain di komunitas dan sektor swasta untuk ikut aktif dalam upaya-upaya tersebut (Sumarto, 2004).

Sementara itu, di tahun 2019 Pemerintah Kota Surakarta menargetkan 7.375 unit rumah dipugar melalui program Perbaikan Rumah Tidak Layak Huni (RTLH) yang digagas Dinas Perumahan dan Pertanahan Kota Surakarta. Namun pada pertengahan tahun, rumah yang diperbaiki baru mencapai 805 unit, hal ini terjadi karena keterbatasan APBD Kota Surakarta. Kasi Pendataan \& Perencanaan Dinas Perumahan dan Pertanahan (Disperum KPP) Kota Surakarta mengatakan bahwa capaian RTLH untuk tahun ini sekitar 7,36\% saja yang alokasinya dari Dana Alokasi Khusus (DAK) APBD 2019. Selain dari DAK dan APBD, Pemerintah Kota Surakarta juga mencarikan anggaran untuk RTLH melalui CSR perusahaan. Pemerintah berharap dengan adanya CSR bisa membantu pemerintah segera merampungkan target penanganan RTLH.

Sebagai perbandingan, di tahun 2016 Pemerintah Kota Surakarta melalui Dinas Perumahan dan Pertahanan mencatat masih terdapat 9.292 unit Rumah Tidak Layak Huni (RTLH) yang tersebar di Kota Surakarta. Pada tahun 2017 mereka berhasil menyelesaikan perbaikan RTLH sebanyak 976 unit rumah, namun di tahun 2018 mengalami penurunan dengan jumlah perbaikan RTLH sebanyak 941 unit rumah, dan ditahun 2019 mereka dikhawatirkan mengalami penurunan kembali jika melihat angka keberhasilan mereka di pertengahan tahun yang baru menyelesaikan 805 unit rumah. 
Dengan adanya konsep collaborative governance yang digagas oleh Pemerintah Kota Surakarta, maka sebanyak lima Badan Usaha Milik Daerah (BUMD) sepakat menyalurkan dana bantuan Corporate Social Responsibility (CSR) guna mendukung pembangunan fasilitas umum puluhan Rumah Tidak Layak Huni (RTLH) di Kota Surakarta. Kelima BUMD tersebut yaitu Perusahaan Daerah Air Minum (PDAM), Perusda Bank Solo, Pergudangan dan Aneka Usaha (PAU) Pedaringan, Perumda Taman Satwa Taru Jurug (TSTJ), serta Perusda Badan Kredit Kecamatan (BKK) Pasar Kliwon.

Selain beberapa BUMD tersebut, beberapa pihak swasta dan komunitas masyarakat juga tertarik untuk menyalurkan dana CSR berbentuk bantuan perbaikan RTLH di Kota Surakarta. Pihak tersebut antara lain, CSR Paguyuban Seruling Mas (Seruan Eling Banyumasan) dan Solo Bersama Selamanya (SBS). Sementara itu, data Dinas Perumahan dan Pertanahan Kota Surakarta juga menunjukkan masih adanya beberapa unit RTLH yang dipugar menggunakan dana CSR dari Bank Jateng. Pemugaran ini dimulai pada bulan Oktober tahun 2019 dengan menggunakan dana CSR Bank Jateng dengan jumlah 41 unit RTLH. Dengan masih berjalannya perbaikan RTLH menggunakan CSR Bank Jateng tersebut, maka Pemerintah Kota Surakarta berharap di akhir tahun 2019 jumlah RTLH yang telah selesai diperbaiki mencapai 846 unit rumah. Jika jumlah tersebut tercapai, maka dapat dipastikan jumlah perbaikan RTLH setiap tahun mengalami penurunan dimulai dari tahun 2016 sampai 2019.

Dengan demikian dengan adanya Perda Kota Surakarta Nomor 2 Tahun 2015 tentang Tanggung Jawab Perusahaan dan dan peraturan lain yang menyertainya secara langsung menyebabkan BUMD, Pemerintah, serta pihak swasta melalui CSRnya memiliki tanggung jawab untuk bersama-sama dengan pemerintah membangun sinergi yang nyata untuk mensejahterakan masyarakat melalui perbaikan Rumah Tidak Layak Huni (RTLH) di Kota Surakarta. Oleh karena itu peneliti tertarik untuk melihat bagaimana kolaborasi pemerintah, BUMD, serta beberapa pihak swasta dalam program perbaikan RTLH di Kota Surakarta melalui Corporate Social Responsibility serta faktor apa yang mendukung dan menghambat terjadinya kolaborasi tersebut. Beberapa tinjauan pustaka yang digunakan dalam penelitian ini antara lain collaborative governance, Corporate Social Responsibility dan Program Perbaikan Rumah Tidak Layak Huni.

Menurut Ansell dan Gash dalam (Febrian, 2016) mendefinisikan collaborative governance sebagai sebuah pengaturan yang mengatur satu atau lebih lembaga publik secara langsung dan terlibat dengan pemangku kepentingan non publik dalam proses 
pengambilan keputusan kolektif bersifat formal, berorientasi konsensus, dan musyawarah yang bertujuan untuk membuat atau mengimplementasikan kebijakan publik atau mengelola program atau aset publik.

Dalam jurnal yang berjudul Collaborative Governance in Theory and Practice yang ditulis oleh Chris Ansell dan Alison Gash, mereka mengatakan bahwa selama beberapa dekade terakhir, bentuk baru dari pemerintahan telah muncul untuk menggantikan mode permusuhan dan manajerial pengambilan kebijakan dan implementasi. Istilah pemerintahan kolaboratif muncul dan membawa para pemangku kepentingan publik dan swasta bersama-sama dalam forum kolektif dengan lembaga-lembaga publik untuk terlibat dalam pengambilan keputusan. Dalam hal ini, mereka membuat model collaborative governance yang sederhana serta mencakup berbagai kepentingan.

Tabel 2. Model Collaborative Governance Ansell and Gash

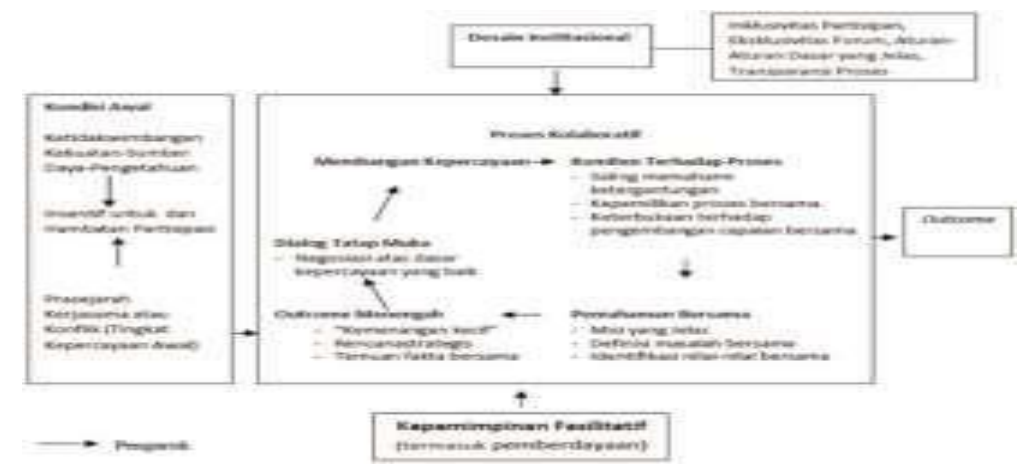

Sumber: Ansel and Gash, 2007

Kondisi awal sebuah kolaborasi dapat memfasilitasi atau mencegah kerjasama antara para pemangku kepentingan dan antara lembaga dan pemangku kepentingan. Ada banyak fenomena yang menyertai antara lain sejarah kelam dimasa lalu, ketidakseimbangan sumber daya yang dimiliki, tingkat kepercayaan. Namun di sisi lain, para pemangku kepentingan memiliki visi bersama untuk apa yang mereka ingin capai melalui kolaborasi dan sejarah kerja sama masa lalu dan saling menghormati.

Kepemimpinan fasilitatif berkaitan dengan musyawarah yang dilakukan oleh stakeholders, penetapan aturan-aturan dasar yang jelas, membangun kepercayaan, memfasilitasi dialog antar stakeholders dan pembagian keuntungan bersama. Desain institusional berkaitan dengan tata cara dan peraturan dasar dalam kolaborasi untuk prosedural proses kolaborasi yang legal, transparansi proses, inklusivitas partisipan, dan eksklusivitas forum.

Selanjutnya, dalam proses kolaboratif merupakan variabel yang penting dimana proses kolaborasi diawali dengan dialog tatap muka yang berkaitan dengan kepercayaan 
yang baik, setelah melakukan dialog tatap muka dengan baik maka akan terbangun suatu kepercayaan yang nantinya akan berpengaruh terhadap komitmen dalam proses kolaborasi, setelah komitmen para stakeholders tinggi akan terjadi suatu pemahaman bersama dalam perumusan masalah, identifikasi nilai-nilai, dan misi yang jelas. Setelah para stakeholders memiliki kesamaan dan kesepahaman, maka akan menentukan rencana strategis untuk menjalankan kolaborasi. Adapun indikator kesuksesan dalam proses tata kelola kolaborasi yaitu, mengikutsertakan semua, transparan dan bertanggung jawab, efektif dan adil; menjamin supremasi hokum, menjamin bahwa prioritas politik, sosial dan ekonomi didasarkan pada konsensus masyarakat, dan memperhatikan yang lemah dalam pengambilan keputusan (Ansell \& Gash, 2007).

Selanjutnya dalam mengukur keberhasilan suatu kolaborasi, menurut DeSeve dalam (Sudarmo, 2011) untuk mengukur keberhasilan collaborative governance dapat diukur melalui delapan indikator yaitu, a) Network structure (struktur jaringan) terdiri dari self governance, lead organization network administrative organization (NAO), b) Commitment to a common purpose (komitmen terhadap tujuan), c) Trust among the participants (adanya saling percaya diantara pelaku/peserta), d) Governance (kejelasan dalam tata kelola) terdiri dari boundary dan exclusivity, rules (aturan-aturan), self determination, network management, e) Access to authority (akses terhadap kekuasaan), f) Distributive accountability atau responsibility (pembagian akuntabilitas /responsibilitas), g) Information sharing (berbagi informasi), h) Access to resources (akses sumber daya).

Literatur-literatur awal yang membahas CSR pada tahun 1950-an menyebut SR sebagai Social Responsibility. Dalam buku karangan Howard R. Bowen yang terbit pada tahun 1953 yang berjudul Social Responsibility of the Businessman dianggap sebagai tonggak CSR modern. Dalam buku tersebut Bowen memberikan definisi awal dari CSR sebagai : “... obligation of businessman to pursue those policies, to makethose decision or to follow those line of action wich are desirable in term of theobjectives and values of our society." (Bowen, 1953). Jenis-jenis Program Corporate Social Responsibility (CSR), menurut Kolter dan Lee (2005) dalam (Dewi \& Rahman, 2016) menyebutkan enam kategori aktivitas CSR, yaitu, a) cause promotions (promosi kegiatan sosial), b) cause related marketing (pemasaran terkait kegiatan sosial), c) corporate societal marketing, d) corporate philanthropy, e) community volunteering, f) socially responsible business practice. 
Menurut data yang diperoleh dari Dinas Perumahan dan Pertanahan Kota Surakarta, di tahun 2019, dengan target perbaikan RTLH yang masih berjumlah 7.375 (tujuh ribu tiga ratus tujuh puluh lima) unit rumah, Pemerintah Kota Surakarta sampai akhir tahun 2019 berhasil melakukan rehab/perbaikan RTLH sebanyak 805 (delapan ratus lima) unit, ditambah 41 (empat puluh satu) unit rumah yang masih dalam proses pengerjaan dan ditargetkan selesai akhir tahun 2019 ini. Dari sejumlah 805 (delapan ratus lima) unit RTLH yang telah selesai diperbaiki, 169 (seratus enam puluh sembilan) unit menggunakan dana DAK, lalu sebanyak 206 (dua ratus enam) unit menggunakan dana APBD, 13 (tiga belas) unit diambil dari dana CSR BUMD, 2 (dua) unit dari dana CSR Seruling Mas, 10 (sepuluh) unit merupakan sumbangan CSR SBS (Solo Bersama Selamanya), dan 405 (empat ratus lima) unit diambil dari dana BSPS. Sementara itu, 41 (empat puluh satu) unit RTLH yang masih dalam proses perbaikan merupakan sumbangan CSR Bank Jateng.

\section{METODE}

Penelitian ini merupakan jenis penelitian deskriptif dengan didukung data kualitatif dimana dalam penelitian ini berusaha untuk mengungkap fakta dari suatu fenomena sosial yang terjadi sebagaimana adanya dan memberikan gambaran secara objektif tentang keadaan atau permasalahan yang mungkin dihadapi secara natural. Lokasi Penelitian ini berada di Kota Surakarta. Penelitian ini dilakukan di Dinas Perumahan dan Pertanahan Kabupaten Surakarta sebagai pihak yang menangani program RTLH dan Sekretaris Daerah sebagai pihak yang menangani CSR, serta pihak lain yang menjadi penyumbang CSR bagi program RTLH, yaitu Perusda Bank Solo, Pergudangan dan Aneka Usaha (PAU) Pedaringan, Perumda Taman Satwa Taru Jurug (TSTJ), Sekretariat Komunitas Solo Bersama Selamanya (SBS), serta Paguyuban Seruling Mas. Teknik pengumpulan data dilakukan melalui metode wawancara dan informan yang diwawancarai dipilih melalui teknik purposive sampling yaitu dengan mengambil beberapa orang yang terlibat ataupun mengetahui mengenai kolaborasi yang dilakukan. Uji validitas data yang digunakan adalah teknik triangulasi sumber dan triangulasi teknik. Sedangkan untuk teknik analisis data menggunakan model analisis data Miles dan Huberman yang terdiri dari pengumpulan data, reduksi data, penyajian data dan penarikan kesimpulan. 


\section{HASIL DAN DISKUSI}

\section{Proses Collaborative Governance}

a) Kondisi awal

Dalam aspek kondisi awal, ketidakseimbangan sumber daya menjadi awal mula dari dibutuhkannya sebuah kolaborasi. Dalam hal ini, kebutuhan rumah tidak layak huni di Kota Surakarta menurut data yang dimiliki Dinas Perumahan dan Pertanahan per tahun 2019 mencapai 7.375 unit rumah. Sedangkan ditahun 2019 tersebut, Pemerintah hanya mampu menyediakan Dana Alokasi Khusus (DAK) untuk 169 unit rumah saja serta APBD untuk 206 unit rumah. Bantuan Stimultan Perumahan Swadaya (BSPS) Provinsi Jawa Tengah yang didapatkanpun hanya mencukupi untuk 405 unit RTLH saja. Disisi lain, pemerintah kota mempunyai target untuk Rencana Program Investasi Jangka Menengah (RPIJM) 2025 bahwa Kota Surakarta bebas dari rumah tidak layak huni serta ada juga target 100-0-100 yang dicanangkan. Berdasarkan hal tersebut, maka ketidakseimbangan sumber daya yang dimiliki Pemerintah Kota dalam Program Perbaikan RTLH menjadikan mereka juga menggandeng pihak lain untuk berkolaborasi.

Dalam aspek kondisi awal yang ditulis oleh Ansell dan Gash, melibatkan poin sejarah masa lalu bisa menjadikan kolaborasi lebih mudah untuk dilakukan. Dalam poin sejarah masa lalu, Pemerintah Kota dan beberapa BUMD sudah melalukan kolaborasi dalam beberapa tahun terakhir. Sehingga dalam prosesnya, mereka sudah mengerti satu sama lain serta sudah tumbuh rasa saling percaya. Dalam dokumen yang dimiliki Dinas Perumahan dan Pertanahan Kota Surakarta, di tahun 2017 misalnya, CSR gabungan BUMD memberikan sumbangan untuk program RTLH sebanyak 10 unit rumah, sedangkan ditahun 2019 ini meningkan menjadi 13 unit rumah. Selain itu, adanya persamaan visi antara Pemerintah Kota dengan pihak-pihak terkait seperti BUMD dan komunitas masyarakat seperti yang sudah dijelaskan dalam sub bab kedua dan ketiga juga menjadi alasan yang kuat untuk melakukan kolaborasi.

b) Desain Institusional

Dalam prakteknya di lapangan, pelaksanaan kolaborasi yang dilakukan didasarkan pada Peraturan Daerah Nomor 2 Tahun 2015 tentang Tanggung Jawab Sosial Perusahaan serta diperkuat oleh Peraturan Walikota Surakarta Nomor 27A Tahun 2018. Dalam Perda Nomor 2 Tahun 2015 Pasal 5 disebutkan bahwa ruang lingkup TJSP adalah bantuan pembiayaan penyelenggaraan kesejahteraan sosial, kompensasi pemulihan, dan atau peningkatan fungsi lingkungan hidup, kesehatan, pendidikan dan memacu 
pertumbuhan ekonomi berkualitas berbasis kerakyatan yang selaras dengan program Pemerintah Daerah.

Selanjutnya Perda Nomor 2 Tahun 2015 Pasal 6 menyebutkan bahwa Perusahaan yang menjalankan usahanya di Daerah baik Badan Usaha Milik Negara (BUMN) dan atau Badan Usaha Milik Daerah (BUMD) dan Perusahaan Swasta yang berbadan hukum yang menghasilkan barang maupun jasa wajib melaksanakan TJSP. Ditambahkan dalam Perwali Nomor 27A tahun 2018 bagian kedua pasal 17 ayat 1 menyebutkan bahwa pengajuan program TJSP oleh kelompok/paguyuban/organisasi masyarakat dapat menginventarisir kegiatan di bidang bina lingkungan sosial dan lingkungaan serta usaha mikro, kecil, dan koperasi. Serta dalam ayat 2 menyatakan kelompok/paguyuban/ organisasi masyarakat menyusun dan mengajukan proposal untuk disampaikan kepada Forkom TJSP.

c) Kepemimpinan Fasilitatif

Di Kota Surakarta sendiri terdapat beberapa aturan atau kebijakan yang diterbitan oleh Pemerintah Kota untuk mandasari sebuah program. Mengenai program perbaikan rumah tidak layak huni (RTLH), Pemerintah Kota memiliki Peraturan Walikota Nomor 54 Tahun 2912 tentang Petunjuk Teknis Pemberian Bantuan Pembangunan/Perbaikan Rumah Tidak Layak Huni Bagi Masyarakat Miskin Kota Surakarta. Secara garis besar, Perwali ini menitikberatkan pada petunjuk teknis pelaksanaan program perbaikan rumah tidak layak huni di Kota Surakarta.

Selanjutnya, mengenai TJSP atau tanggung jawab sosial perusahaan yang mendasari terjadinya collaborative governance, Pemerintah Kota Surakarta memiliki Peraturan Daerah Nomor 2 Tahun 2015 tentang Tanggung Jawab Sosial Perusahaan. Untuk mendukung pelaksanaan Perda tersebut, Pemerintah Kota Surakarta menerbitkan Peraturan Walikota Surakarta Nomor 27A Tahun 2018 Tentang Petunjuk Pelaksanaan Peraturan Daerah Kota Surakarta Nomor 2 Tahun 2015 Tentang Tanggung Jawab Sosial Perusahaan. Dalam Perwali tersebut lebih dijabarkan lagi mengenai hal-hal secara detail mengenai TJSP termasuk kolaborasi yang perlu dilakukan pemerintah dan perusahaan serta komunitas yang ada di Surakarta.

Dalam aspek ini, pemerintah kota juga diharapkan untuk membangun kepercayaan agar kolaborasi yang dilakukan dapat berjalan dengan baik dan berkesinambungan. Sementara itu, menurut wawancara dengan beberapa informan, mereka menyatakan bahwa Pemerintah Kota Surakarta sudah membangun kepercayaan dengan baik 
sehingga kolaborasi yang dilakukan berjalan dengan nyaman dan berkesinambungan dalam beberapa tahun.

d) Proses Kolaboratif

Aspek ini diawali dengan dialog tatap muka atau pertemuan yang dilakukan agar tercipta kesepahaman atau kesepakatan mengenai kolaborasi yang dilakukan. Dalam prakteknya, hal ini juga dilakukan oleh Pemerintah Kota Surakarta untuk mengawali terciptanya kolaborasi. Selanjutnya jika dimungkinkan untuk dilakukannya sebuah pertemuan, maka Sekretariat Daerah bagian Perekonomian yang membidangi khusus mengenai CSR atau TJSP, mereka akan memfasilitasi untuk tempat dan susunan acara dari pertemuan tersebut. Sejalan dengan adanya forum tersebut, untuk memudahkan komunikasi dalam forum tersebut dibuatlah grup whatsapp yang berisi perwakilan perusahaan di daerah atau BUMD dengan perangkat daerah termasuk Walikota dan Dinas Perumahan dan Pertanahan selaku pelaksana program perbaikan RTLH. Selain itu sebelum penyerahan dana CSR mereka juga berkomunikasi dengan Dinas terkait termasuk Dinas Perumahan dan Pertanahan Kota Surakarta untuk meminta data kelurahan mana saja yang dimungkinkan untuk menjadi sasaran.

Dengan dilakukannya dialog tatap muka maupun melalui grup whatsapp, maka akan membentuk suatu kepercayaan yang tinggi diantara mereka. Kepercayaan yang tinggi juga terbentuk dikarenakan adanya sejarah masa lalu atau pengalaman mereka di tahun sebelumnya yang juga pernah bekerjasama seperti yang sudah dijelaskan di aspek sebelumnya. Selain kepercayaan, komitmen juga akan terbentuk dengan sendirinya ketika melihat kolaborasi yang semakin terjaga. Kepercayaan yang ada diantara mereka mempengaruhi komitmen terhadap proses yang juga semakin tinggi ketika pelaporan dan pertanggungjawaban yang dilakukan Dinas Perumahan dan Pertanahan juga jelas dan tepat waktu. Pelaporan yang dilakukan Dinas terkait dilakukan secara berjenjang selama proses kolaborasi berlangsung. Hal ini dilakukan untuk menjaga harmonisasi dalam berkolaborasi serta menjaga profesonalitas dalam kolaborasi.

Dengan adanya komitmen dan keterbukaan dalam proses kolaborasi tersebut maka akan tercipta harmonisasi yang nyata dan dengan sendirinya akan dilakukan secara terus menerus untuk beberapa waktu atau tahun kedepan. Dalam teori yang disebut oleh Ansel dan Gash hal ini dikategorikan sebagai "kemenangan kecil” yang dihasilkan dari adanya proses kolaborasi tersebut. Outcome dari kolaborasi yang dilakukan yaitu adanya 
rumah layak huni yang bertambah di kota Surakarta serta berjalannya program Perbaikan RTLH.

\section{Faktor Pendukung dan Penghambat Collaborative Governance}

a) Network Structure

Dalam prakteknya dalam kolaborasi ini masuk dalam kategori self governance, dimana tidak adanya ketentuan hukum yang mengikat antar anggotanya namun semua anggota dalam kolaborasi ini terlibat secara aktif dan profesional sesuai tanggung jawabnya masing-masing. Adanya kesadaran yang tinggi disetiap anggotanya untuk saling berkolaborasi untuk mensukseskan program perbaikan RTLH di Surakarta sekaligus berpartisipasi untuk aspek kemanusiaan dan sosial menjadi kelebihan sekaligus tergolong sebagai faktor pendukung dalam kolaborasi ini. Selain itu, kelemahan dalam kategori ini antara lain keputusan yang diambil didominasi oleh satu pihak, dalam hal ini Pemerintah Kota. Dalam kategori ini, para anggota yang terlibat tidak mengetahui pembagian kerja yang dilakukan oleh masing-masing instansi yang terlibat dalam kolaborasi.

b) Commitment to a Common Purpose

Kemauan yang kuat diantara para anggotanya menjadi nilai tambah bagi kolaborasi ini. Meskipun pada dasarnya, dua hal yang menjadi alasan mereka untuk berkolaborasi berbeda. Dari pihak perusahaan serta komunitas masyarakat, alasan mereka adalah untuk menyalurkan dana CSR atau TJSP sesuai dengan porsinya masing-masing dan dilandasi oleh aturan yang ditetapkan, sedangkan dari pihak pemerintah kota alasan mereka perlu berkolaborasi ialah agar program perbaikan RTLH yang mereka canangkan dapat berjalan dengan baik dan semakin banyak Rumah Layak Huni yang ada di Kota Surakarta. Pada prosesnya, kolaborasi yang dilakukan dapat berjalan dengan baik serta tingginya komitmen yang ada diantara anggota serta rasa percaya antar sesama anggota menjadi kelebihan yang ada dalam kolaborasi ini. Komitmen yang penuh dan tinggi menjadi modal utama dalam kolaborasi yang dilakukan. Komitmen yang tinggi memungkinkan kolaborasi dapat berjalan lebih dari beberapa kali atau beberapa tahun lamanya.

c) Trust Among a Participants

Rasa percaya antar sesama anggota yang timbul sejalan dengan adanya komitmen yang kuat dalam berkolaborasi serta sudah sesuai dengan visi misi yang disepakati para anggotanya. Para partisipan atau anggota dalam kolaborasi ini mempercayai informasi 
yang didapatkan dan mereka saling berbagi informasi antar partisipan satu sama lain. Kepercayaan yang timbul diantara mereka juga dikarenakan adanya hubungan yang profesional antar individu dan keinginan yang kuat untuk mencapai tujuan bersama seperti yang sudah dibahas dalam sub bab sebelumnya.

\section{d) Governance}

Beberapa faktor yang mempengaruhi tata kelola antara lain boundary dan exlusivity, rules, self determination, dan network management. Pertama dalam boundary dan exlusivity, membahas mengenai pembatasan perilaku yang perlu dilakukan serta batasan mengenai mana yang menjadi anggota kelompok atau yang bukan anggota. Dalam prakteknya, sudah terdapat pembatasan yang dilakukan oleh para anggota yang terlibat dalam kolaborasi. Pembatasan yang dilakukan mengenai peran serta mereka dalam kolaborasi yang sudah diatur dalam Peraturan Walikota Nomor 27A Tahun 2018 maupun peraturan lain berdasar atas instansinya masing-masing sehingga terjaganya profesionalitas serta kesepahaman yang tinggi mengenai peran mereka masing-masing. Begitu pula dalam exlusivity, dalam Peraturan Walikota Nomor 27 A Tahun 2018 juga disebutkan bahwa yang menjadi anggota dalam forum TJSP merupakan perwakilan dari perusahaan yang memberikan dana TJSP dan perangkat pemerintah daerah. Selanjutnya dalam rules membahas mengenai sejumlah pembatasan-pembatasan perilaku anggota komunitas dengan ancaman bahwa mereka akan dikeluarkan jika perilaku mereka menyimpang dan tidak sesuai atau bertentangan dengan kesepakatan yang telah disetujui bersama. Dalam kolaborasi yang dilakukan, belum terdapatnya aturan-aturan tersebut karena mereka melakukan kolaborasi atas dasar sukarela atau kesadaran masingmasing dan informal sehingga tidak ada hal apapun yang mengikat dalam kolaborasi. Pembatasan-pembatasan yang ada dalam kolaborasi lebih dikarenakan berbedanya peran yang ada disetiap anggota kolaborasi serta status asal mereka.

Selanjutnya dalam self determination dijabarkan mengenai kebebasan untuk menentukan bagaimana kolaborasi akan dijalankan dan siapa yang diijinkan untuk menjalankannya. Dalam praktiknya, kolaborasi dijalankan dengan profesional antar anggotanya atas dasar satu kepercayaan, visi, dan misi yang dianut bersama. Seperti yang sudah dijabarkan dalam sub bab sebelumnya, kolaborasi dijalankan sesuai peran dan kewajiban yang dimiliki setiap anggotanya berdasar pada peraturan dan kesepakatan yang ada. 
Dan yang terakhir dalam network management membahas berkenaan dengan resolusi penolakan/tantangan alokasi sumber daya, kontrol kualitas, dan pemeliharaan organisasi. Dalam kolaborasi ini, semua sumber daya dan kualitas dikontrol oleh pemerindah kota dalam hal ini diserahkan kepada Dinas Perumahan dan Pertanahan sesuai dengan tugas pokok dan fungsinya dalam program perbaikan rumah tidak layak huni (RTLH). Dalam network management, beberapa individu dari unsur perusahaan daerah atau pihak pemberi CSR akan cenderung pasif setelah mereka menyerahkan dana CSR.

\section{e) Acces to authority}

Dalam aspek ini dibahas mengenai tersedianya standar-standar atau ukuranukuran ketentuan atas prosedur-prosedur yang jelas dan diterima secara luas. Pada umunya, mereka memberikan beberapa network otoritas guna mengimplementasikan keputusan-keputusan atau menjalankan pekerjaannya. Dalam kolaborasi ini, Dinas Perumahan dan Pertanahan selau unsur pemerintah kota diberikan keleluasaan untuk menjalankan pekerjaannya dalam program perbaikan RTLH. Untuk sisi positifnya, mereka dapat menjalankan program sesuai dengan standar dan ukuran yang telah mereka tetapkan sebelumnya. Namun untuk sisi negatifnya, hal ini menjadikan unsur lain dalam kolaborasi menjadi pasif dan hanya melakukan pengawasan secara tidak langsung. Disisi lain, belum adanya aturan yang jelas dalam organisasi atau komunitas mengenai pemberian CSR dalam program RTLH sebagai target utama mereka. Hal ini dikarenakan belum adanya aturan yang jelas serta dikhususkan bagi komunitas atau perusahaan untuk memberikan dana CSR dalam program RTLH seperti yang sudah dibahas dalam aspekaspek sebelumnya.

\section{f) Distributive Accountability/Responsibility}

Aspek ini mengharapkan akan adanya penataan, pengelolaan, manajemen secara bersama-sama dengan stakeholders lainnya dan berbagi sejumlah pembuatan keputusan kepada seluruh anggota jaringan, dan dengan demikian berbagi tanggung jawab untuk mencapai hasil yang diinginkan. Namun dalam kenyataannya dalam kolaborasi yang dilakukan Pemerintah Kota Surakarta dengan beberapa perusahaan daerah dan komunitas daerah, keputusan utama masih dilakukan oleh Pemerintah Kota meskipun melalui diskusi dalam pertemuan. Dalam prosesnya, setelah program berjalan melalui kolaborasi yang dilakukan, unsur perusahaan dan komunitas daerah hanya bersifat pasif atau melakukan pengawasan secara informal. Meskipun hal tersebut menjadi 
kekurangan dalam kolaborasi ini, masih ada satu hal yang dapat menjadi faktor utama penentu keberhasilan kolaborasi, hal tersebut adalah profesionalitas yang masih terjaga dengan baik. Profesionalitas yang baik menjadi salah satu kunci yang harus dijaga dan ditingkatkan.

\section{g) Information Sharing}

Dalam sub bab ini, membahas mengenai kemudahan akses informasi bagi para anggota, perlindungan privacy (kerahasiaan identitas pribadi seseorang) dan keterbatasan akses bagi yang bukan anggota sepanjang bisa diterima oleh semua pihak. Prakteknya dalam kolaborasi yang dilakukan, akses informasi yang didapatkan oleh para anggota kolaborasi bersifat terbuka dan menyampaikan informasi satu sama lain. Hal ini dikarenakan sikap para anggota kolaborasi yang bersikap profesional dan mengerti akan tanggung jawabnya masing-masing. Data yang diakses pemerintah kota pun sudah go publik sehingga mudah diakses oleh semua pihak.

h) Acces to Resources

Dalam aspek ini membahas mengenai akses sumber daya yang dimiliki oleh anggota baik berupa sumber daya keuangan, teknis, sumber daya manusia, maupun sumber daya lain yang ada dalam kolaborasi ini. Mengenai sumber daya keuangan, seperti yang sudah dijelaskan dalam pembahasan diatas, dana yang dimiliki oleh pemerintah dalam program RTLH ini terbatas. Dengan keterbatasan dana tersebut, maka beberapa perusahaan BUMD yang ada di Surakarta berkomitmen ikut terlibat membantu pemerintah melalui dana CSRnya. Selain itu terkait sumber daya teknis yang mencakup biaya stimulan serta upah tukang atau pekerja pelaksana program RTLH. Dilansir dalam SuaraMerdeka.com yang dipublikasikan pada Minggu, 21 April 2019 Pemerintah Kota menambah dana stimulan menjadi sekitar 17,5 juta rupiah. Hal ini dilakukan berdasarkan evaluasi serta masukan dari masyarakat. Selain itu, adanya tambahan biaya bagi upah pekerja.

\section{KESIMPULAN}

Dalam analisis mengenai proses collaborative governance menggunakan teori yang ditulis oleh Ansell dan Gash, terdapat ketidakseimbangan sumber daya dimana akhirnya Pemerintah Kota meminta bantuan pihak lain yaitu BUMD dan komunitas masyarakat melalui dana CSR. Selain itu Pemerintah Kota dan beberapa BUMD sudah melalukan kolaborasi dalam beberapa tahun terakhir, sehingga dalam prosesnya mereka sudah 
mengerti satu sama lain serta sudah tumbuh rasa saling percaya. Dalam prakteknya di lapangan, pelaksanaan kolaborasi yang dilakukan didasarkan pada Perda Nomor 2 Tahun 2015 tentang Tanggung Jawab Sosial Perusahaan serta diperkuat oleh Perwali Surakarta Nomor 27A Tahun 2018 dan Perwali Nomor 54 Tahun 2912 tentang Petunjuk Teknis Pemberian Bantuan Pembangunan/Perbaikan Rumah Tidak Layak Huni bagi masyarakat miskin Kota Surakarta. Pertemuan difasilitasi oleh Sekretariat Daerah bagian perekonomian serta disiapkan tempat dan berita acara oleh mereka jika dimungkinkan. ntuk memudahkan komunikasi dalam forum tersebut dibuatlah grup whatsapp yang berisi perwakilan perusahaan di daerah atau BUMD dengan perangkat daerah termasuk walikota dan Dinas Perumahan dan Pertanahan selaku pelaksana program perbaikan RTLH. Hal ini juga dilakukan untuk melaporkan mengenai proses dari perbaikan rumah tidak layak huni yang sedang dilakukan maupun laporan-laporan lain yang dimungkinkan. Hal ini juga menumbuhkan rasa saling percaya yang tinggi, komitmen, dan kesamaan visi misi yang jelas diantara mereka akan selalu terjaga. Selanjutnya faktor pendukung dan penghambat collaborative governance bahwa kolaborasi ini masuk dalam kategori self governance dimana tidak adanya ketentuan hukum yang mengikat antar anggotanya namun semua anggota dalam kolaborasi ini terlibat secara aktif dan profesional. Namun keputusan yang diambil masih didominasi oleh satu pihak, yaitu Pemerintah Kota. Meskipun pihak lain bersifat pasif, hal itu tidak menjadikan kolaborasi yang dilakukan hanya bersifat sementara maupun monoton. Hal ini dikarenakan alasanalasan serta komitmen yang kuat terhadap proses diantara mereka terus berjalan. Komitmen yang penuh dan tinggi menjadi modal utama dalam kolaborasi yang dilakukan. Rasa percaya antar sesama anggota yang timbul sejalan dengan adanya komitmen yang kuat dalam berkolaborasi serta sudah sesuai dengan visi misi yang disepakati para anggotanya juga menjadi faktor pendukung kolaborasi yang dilakukan. Disisi lain, sebagai faktor penghambat kolaborasi ternyata belum adanya aturan yang jelas dalam organisasi atau komunitas mengenai pemberian CSR dalam program RTLH sebagai target utama mereka. Aturan yang ada hanya sebatas keharusan bagi BUMD maupun komunitas masyarakat untuk menyalurkan dana CSR mereka, selanjutnya mereka menunggu rekomendasi Pemerintah Kota untuk target penyalurannya. Berdasarkan hasil penelitian tersebut maka direkomendasikan pembuatan aturan khusus oleh Pemerintah Kota Surakarta baik dalam bentuk Peraturan Daerah, Peraturan Walikota, atau apapun yang berisi diwajibkannya pemberian dana CSR yang dilakukan 
oleh Perusahaan swasta atau BUMD serta komunitas masyarakat ke arah pemenuhan Program Perbaikan Rumah Tidak Layak Huni (RTLH) dan keterlibatan anggota kolaborasi dalam pengawasan yang dilakukan secara langsung dilapangan serta penataan, pengawasan, serta pembagian tugas yang lebih jelas dan formal dalam kolaborasi yang dilakukan perlu ditingkatkan lagi.

\section{REFERENSI}

Abdulsyani, (1994). Sosiologi Skematika, Teori, dan Terapan. Jakarta: Bumi Aksara.

Ansell, C. \& Gash, A. (2007). Collaborative Governance in Theory and Practice. Journal of Public Administration Research and Theory.

Bowen, H. R. (1953). Social Responsibility of the Businessman. New York: Harper and Borthers.

Dewi, R. M. \& Rahman, A. (2016). Implementasi Corporate Social Responsibility (CSR) PT. Aetra Air Jakarta. Jurnal Visi Komunikasi, 15(2), 158-170.

Febrian, R. A. (2016). Collaborative Governance dalam Pembangunan Kawasan Perdesaan (Tinjauan Konsep dan Regulasi). Jurnal Pemerintahan, Politik dan Birokrasi, II(1), 200-208.

Hartman, C., Hofman, P., Stafford, E. \& Bruijin. (2002). Environmental Collaboration: Potential and Limits. 1st ed. Boston: Kluwer Academic Publishers.

Putera, R. E. (2007). Analisis Terhadap Program-program Penanggulangan Kemiskinan dan Pemberdayaan Masyarakat di Indonesia. Jurnal Demokrasi, VI(1), 37-62.

Rahajeng, M. S. \& Manaf, A. (2015). Bentuk-Bentuk Kemitraan Pemerintah, Swasta dan Masyarakat dalam Upaya Keberlanjutan Program Penataan Lingkungan Permukiman Berbasis Komunitas (Studi Kasus: Kabupaten Kendal dan Kota Pekalongan). Jurnal Pengembangan Kota, III(2), 112-119.

Sridharan, R. \& Simatupang, T. M. (2009). Managerial Views of Supply Chain Collaboration; an Empirial Study. Gadjah Mada International Journal Of Bussines, 11(2), 253-373.

Sudarmo. (2011). Isu-isu Administrasi Publik dalam Perspektif Governance. Solo: Smart Media.

Sumarto, H., 2004. Inovasi, Partisipasi Dan Good Governance. Jakarta: Yayasan Obor Indonesia. 